\title{
Variability in colour, metallic lustre, and body size of Carabus arvensis Herbst, 1784 (Coleoptera: Carabidae) in relation to habitat properties
}

\author{
Germund Tyler
}

Tyler, G. 2010: Variability in colour, metallic lustre, and body size of Carabus arvensis Herbst, 1784 (Coleoptera: Carabidae) in relation to habitat properties. — Entomol. Fennica 21: 90-96.

Objectives are to elucidate whether populations of Carabus arvensis Herbst, 1784 from contrasting habitats differ in (i) colour, (ii) brightness of metal lustre, or (iii) body size (length of elytra, of elytra + pronotum, and width of pronotum). Two large populations were studied, originating from (a) open heathland, being a remnant from more widespread heaths during former centuries, and (b) mature pine forest established 100-150 years ago on sandy agricultural land. Heath individuals had significantly more brilliant metal lustre and mostly lighter, vivid copper colour than pine forest individuals, which were typically black with a violet shade and slightly larger in size. The two populations are nowadays isolated, which was probably not the case 1-2 centuries ago, when both sites studied were treeless. The usually blackish colour of the forest population could be a recent adaptation to the changed environment, though some influence of processes such as genetic drift cannot be excluded.

G. Tyler, Department of Ecology, Lund University, Runslingan 8 A, SE-22477 Lund, Sweden; E-mail: germund.tyler@ekol.lu.se

Received 3 December 2009, accepted 1 February 2010

\section{Introduction}

Metal lustre and colours other than pigments in beetles depend on the microstructure of their surfaces, thin layers or lamellae of chitin with great ability to reflect light. Depending on the structure of these layers and their angle to incident light, various colours and varying brightness of the metal lustre may appear. Light of different wavelengths may be reflected in different directions, which influences the colour appearance. Chitin surfaces composed of several layers may strengthen the metal colour, or produce different colours at different angles to incident light. In other cases, however, special surface coatings on top of the chitin lamellae can homogenise the colour appearance. In a recent review of structural colour mechanisms in beetles Seago (2009) concluded that for "iridescence" there are three mechanistic groups: "multilayer reflectors, threedimensional phytonic crystals and diffraction gratings".

There is some relationship between metal lustre / colour of carabid beetles and the type of habitat where they occur. Species of open-land habitats, more exposed to direct sunlight and energy influx, seem often to have more brilliant colours and metal lustre than species living on the forest floor. Moreover, species active in the daytime are often brighter than species active in the nights. 
Good examples among the Carabidae in northern and central Europe are two widespread and often very common open-land species, Harpalus affinis (Schrank, 1781) and Poecilus versicolor (Sturm, 1824), whereas most species of the genus Pterostichus Bonelli, 1810, mainly found in forests and largely night-active, are black with weak or no metallic lustre.

However, intraspecific differences in colour and lustre of carabids inhabiting different types of habitats within a small geographical area are often less apparent or less often reported. In the carabid genus Ceroglossus Solier, 1848 (closely related to Carabus Linnaeus, 1758), despite the remarkable colour polymorphism of these ground beetles, the colour pattern is geographically linked and not species-specific, which suggests that some environmental factors are involved in determining the pattern (Okamoto et al. 2001). Frania (1982) reported a significant body colour polymorphism between populations of Elaphrus americanus Dejean, 1831 from subalpine parkland and temperate forests in western NorthAmerica, either maintained by selection or independently by isolation.

Carabus arvensis Herbst, 1784 (=arcensis auct.), a highly variable species, was selected for a study of possible differences in colour, metal lustre and body size between one pine forest population and one open heath (moor land) population in the province of Scania, south Sweden. This species is characterised as "xero-thermophilic", occurring on sandy or on peaty (mainly mor) soil. It has a wide distribution range, extending from Western Europe eastwards through Ukraina and Russia including parts of Siberia to Japan, though subdivided in several subspecies or subspecies groups (Deuve 2004). The Scandinavian populations belong to the ssp. arvensis. There are several distribution gaps, e.g. in northern and central Europe, apparently caused by unsuitable environmental conditions in many areas, at least nowadays. In north-northwest Europe it is typical and often dominant in heath vegetation, though it also occurs in pine forests and forest clearings (Lindroth 1985, Turin et al. 2003). In Hungary it is mainly found in the forest edges (Magura 2002). In areas surrounding the southern parts of the Baltic Sea, where heaths are nowa- days rare or lacking, it is mainly a species of pine forest on sand (Szyszko et al. 1978). In Sweden it is rather rare and at least nowadays only local, though found in several sites in the southern parts of the country.

C. arvensis is brachypterous and has a low power of spreading. It is considered to be active during both days and nights (Lauterbach 1964). It hibernates as imago. Imagines occur from early spring until autumn, young adults appearing in August or September. Dormancy from July or early August until early spring is assumed for old adults (Storre et al. 1996), and imagines may thus be active during at least two seasons.

The body size of $C$. arvensis seems to differ not only among regions and subspecies but probably also among habitats supporting the same subspecies in the same region. Total body length ranges 13-25 mm (Imura \& Muzisawa 1996), though the north European subspecies rarely exceeds $20 \mathrm{~mm}$ in total length. Tyler (2008a) reported consistent differences in body size between populations of several Carabus species from the same general habitat type - beech forest - developed on contrasting soils, indicating a body size relation to soil properties or differences in forest floor vegetation. Also mechanical habitat disturbance (Garbalinska \& Sklodowski 2008, Weller \& Ganzhorn 2004) and climate (Ikeda et al.2006) may influence the body size of Carabus species.

Considerable intraspecies variability is known in C. arvensis. The objectives of this study are to find out if variability is related to habitat properties. Two large but at least nowadays isolated populations from contrasting habitats were studied with respect to (i) colour, (ii) brightness of metal lustre, or (iii) body size (length of elytra, of elytra + pronotum, and width of pronotum). Individuals of the two populations originated from (a) an open heath, constituting an isolated remnant from more widespread heath lands during former centuries, and (b) a large mature pine forest established 100-150 years ago on sandy agricultural land in order to reduce severe aeolic erosion. These are two of the very few vigorous populations of this species known from Scandinavia. Both sites are situated in the south-central parts of the province of Scania, south Sweden. 


\section{Materials and methods}

\subsection{Characteristics of the area studied}

The climate of the area is cool-temperate, subhumid and suboceanic. Winter temperatures are on average +1 to $-3{ }^{\circ} \mathrm{C}$, and mean temperature of the warmest months 16 to $17^{\circ} \mathrm{C}$. Annual precipitation sums range from ca $600 \mathrm{~mm}$ in the lowland (F-site, below) to ca $800 \mathrm{~mm}$ in the upland (Hsite).

The pine forest (F-site) is located in an outwash plain (sandur) with a total area of ca 100 $\mathrm{km}^{2}$ in south Sweden (Greenwich ca $55^{\circ} 40^{\prime} \mathrm{N}$; $13^{\circ} 30^{\prime} \mathrm{E}$ ). The plain was formed at the end of the last glaciation, deposited in a glacial river and its lake. The wholly dominating particle size fraction of the surface soil is fine sand $(0.06-0.20 \mathrm{~mm})$. The area is flat and nearly horizontal, lacking distinct elevations and situated 23-28 m above sea level, ca $30 \mathrm{~km}$ from the Baltic coast. It has a long history of agriculture. Most parts were welldrained open land and still remain so. Wind erosion became a problem in the late $18^{\text {th }}$ and the $19^{\text {th }}$ centuries. The most affected parts were gradually planted with pine (Pinus sylvestris L.). Almost continuous pine forest, $50-150$ y old, nowadays covers about $20 \mathrm{~km}^{2}$ of the outwash plain, the surrounding land being almost treeless pastures, some cultivated ground or abandoned fields (Tyler 2008b). In the interior parts of the forest, where the species was sampled, the ground is slightly undulating by the presence of fossil sand dunes. The soil here is non-calcareous and partly podzolised, the topsoil $\mathrm{pH}$ being ca 4 . The forest floor is generally poor in vascular plant species, dominated by the grass Deschampsia flexuosa (L.) Trin. and often by thick carpets of forest mosses. The forest is ungrazed by cattle but has a fair stock of red deer.

The heath (H-site) is situated ca $35 \mathrm{~km} \mathrm{~N}$ of the F-site, at higher elevation, 150-160 $\mathrm{m}$ a.s.1., on somewhat undulating ground, formed by moraine deposits from the surrounding and underlying gneiss bedrock. This ca 40 ha large heath constitutes the main remnant of a former heath land that covered appreciable areas of this region up to the end of the $19^{\text {th }}$ century. Its soil is rich in stones and boulders, the dominating texture being fine sand-sand $(0.06-2 \mathrm{~mm})$. The ground is podzoli- sed with a distinct, acid organic mor (raw humus) horizon. The vegetation is dominated by heather, Calluna vulgaris (L.) Hull, and grasses as Agrostis capillaris L. and Deschampsia flexuosa (L.) Trin. together with several small subdominant acid-soil herbs. Structurally it is a heathergrass mosaic composed of $1-5 \mathrm{~m}^{2}$ patches of the respective life form, with scattered Juniperus communis L. shrubs. The heath is extensively grazed by cattle and parts of it are being burnt at intervals, though its central parts where the study was located had not been burnt for at least 15 years. The heath is nowadays mainly surrounded by forest or forested mires.

\subsection{Fieldwork and analyses}

Cylindrical plastic pitfall traps with a very smooth inner surface, diam. $75 \mathrm{~mm}$, length 100 $\mathrm{mm}$, were installed vertically with the upper edge slightly below the soil surface. This length and surface property made it impossible for carabids to escape along the cylinder walls even with many individuals captured. They were arranged along transects in different parts of the sites (habitats), ten traps in each with an equidistance of ca 5 $\mathrm{m}$. Totally 40 traps (four transects), were installed in interior parts of the H-site, and totally 30 traps (three transects) in the interior parts of the pine forest (F-site). That only 30 traps were located in the forest site was due to some previous knowledge about the high density of the $C$. arvensis population there.

The traps were installed on 18 April (H-site) and on 19 April (F-site), 2009. They were emptied continuously twice a week until 5 July. Collected individuals were killed in gaseous ethyl acetate, a chemical previously known not to change the colour or metal reflex of this species, and subsequently stored dry at ca $22{ }^{\circ} \mathrm{C}$ until the middle of July, when all measurements and colour estimates were performed.

Size variables measured (at a magnification of $5 \times$ ) were (i) length of elytra (from the front margin of the scutellum to the peaks of elytra), (ii) length of elytra + pronotum (from the centre of the front margin of the pronotum to the peaks of the elytra), and (iii) width of the pronotum where widest. Colour and brightness of the metal lustre of elytra and pronotum were estimated in full sun- 
Table 1. Size variables $(\mathrm{mm})$ in males and females of Carabus arvensis from the heath land (H-site) and from the forest (F-site). Means $\pm S . E$., and (in brackets) total ranges measured. Means $\pm S$.E. of the same variable, followed by different letters, differ at $p \leq 0.05$.

\begin{tabular}{lccc}
\hline Site and sex & Length elytra & Length elytra+pronotum & Width pronotum \\
\hline H-site, males, $N=61$ & $9.55 \pm 0.05 \mathrm{a}(8.6-10.6)$ & $13.02 \pm 0.06 \mathrm{a}(11.9-14.1)$ & $4.85 \pm 0.02 \mathrm{a}(4.3-5.2)$ \\
F-site, males, $N=39$ & $9.83 \pm 0.07 \mathrm{~b}(9.0-11.0)$ & $13.42 \pm 0.09 \mathrm{~b}(12.4-14.8)$ & $5.04 \pm 0.02 \mathrm{~b}(4.5-5.5)$ \\
H-site, females, $N=95$ & $10.53 \pm 0.05 \mathrm{c}(9.3-11.5)$ & $14.10 \pm 0.06 \mathrm{c}(12.8-15.4)$ & $5.10 \pm 0.03 \mathrm{~b}(4.4-5.6)$ \\
F-site, females, $N=71$ & $10.68 \pm 0.06 \mathrm{~d}(9.9-11.6)$ & $14.27 \pm 0.06 \mathrm{~d}(13.1-15.3)$ & $5.31 \pm 0.03 \mathrm{c}(4.8-5.7)$ \\
\hline
\end{tabular}

light directed and observed at almost right angle to the length axis of the carabid body. Estimates were carried out around noon during a few days in the middle of July, using the Colour atlas of the Swedish Standardization Commission (SIS 1990) comprising 1526 systematically arranged colour hues. In the present paper the scales were somewhat simplified and given English colour nominations. Brightness of the metal lustre was estimated for pronotum and elytra using a 5-degree scale, where 1 is equal to no, or almost no metal lustre, and 5 equal to a very bright metal lustre. Individuals from the two sites were treated according to a randomised scheme, in order to minimise any bias caused by the position of a particular individual in the entire material.

As there are no detectable differences in the variables studied among different transects within the same site, the transects of each site are treated as one unit. Means \pm S.E. of measured variables, and significance of differences between means, were calculated for each site and sex using ANOVA + paired $t$-test according to Bailey (1969, pp. 48, 193).

\section{Results}

\subsection{Male-to-female ratio}

Number of individuals captured and studied were 156 (39\% males) in the H-site, and 110 (35\% males) in the F-site. The male-to-female ratio was thus as low as $0.54-0.64$.

\subsection{Size measurements}

Length of elytra, of elytra + pronotum, and width of pronotum differed slightly, but (due to the rather large material studied) mostly significantly $(p<0.05$ or $<0.01$ ), with consistently higher values for the forest (F-site) than for the heath land (H-site) population (Table 1). This was true for both males and females, Means of length variables were $2.9-3.1 \%$ higher in males and 1.2 $1.4 \%$ higher in females in the $\mathrm{F}$-site than in the $\mathrm{H}$ site. Mean width of pronotum differed $3.9 \%$ in males and $4.1 \%$ in females, in favour of the F-site. Females were on average 6-8\% larger than males, a difference in favour of females that is normal compared to most other species of Carabus.

\subsection{Estimate of metal lustre}

The metal lustre of males was somewhat stronger than of females in both sites. However, the difference between the two sites was more drastic in both males and females. Using the 5-degree scale of estimate, the mean lustre of male elytra was ca $40 \%$ stronger in the $\mathrm{H}$-site than in the F-site (absolute values in Table 2). Mean lustre of male pro-

Table 2. Metal lustre of pronotum and elytra in males and females of Carabus arvensis from the heath land ( $\mathrm{H}$-site) and the forest (F-site), estimated according to a 5-degree scale. Means $\pm S$.E., and (in brackets) total ranges. Means $\pm S$.E. of the same variable, followed by different letters, differ at $p \leq 0.05$. Number of individuals, see Table 1.

\begin{tabular}{lll}
\hline Site and sex & Lustre elytra & Lustre pronotum \\
\hline H-site, males & $4.3 \pm 0.1 \mathrm{a}(3-5)$ & $4.6 \pm 0.1 \mathrm{a}(3-5)$ \\
F-site, males & $3.0 \pm 0.1 \mathrm{~b}(2-5)$ & $3.5 \pm 0.1 \mathrm{~b}(2-5)$ \\
H-site, females & $3.7 \pm 0.1 \mathrm{c}(2-5)$ & $4.3 \pm 0.1 \mathrm{a}(3-5)$ \\
F-site, females & $2.2 \pm 0.1 \mathrm{~d}(1-4)$ & $3.1 \pm 0.1 \mathrm{c}(2-5)$ \\
\hline
\end{tabular}


Table 3. Per cent distribution of colour shades of elytra in males and females of Carabus arvensis from the heath land ( $\mathrm{H}$-site) and the forest (F-site), estimated according to SIS (1990) and given colour nominations in English. Number of individuals, see Table 1.

\begin{tabular}{|c|c|c|c|c|}
\hline \multirow{2}{*}{ Colour shade } & \multicolumn{2}{|c|}{ Males } & \multicolumn{2}{|c|}{ Females } \\
\hline & H-site & F-site & $\mathrm{H}$-site & F-site \\
\hline \multicolumn{5}{|l|}{ Bright copper } \\
\hline to copper reddish & 47 & 8 & 28 & 0 \\
\hline Dark copper to brownish & 26 & 10 & 39 & 10 \\
\hline shade & 11 & 0 & 7 & 0 \\
\hline Blackish brown & 8 & 4 & 20 & 12 \\
\hline Black with greenish shade & e 8 & 8 & 2 & 2 \\
\hline Black with violet shade & 0 & 41 & 2 & 35 \\
\hline Black, no metal lustre & 0 & 29 & 2 & 41 \\
\hline
\end{tabular}

notum was ca $30 \%$ stronger in the $\mathrm{H}$-site, of female elytra ca $70 \%$ stronger, of female pronotum ca $40 \%$ stronger in the $\mathrm{H}$-site than in the F-site. All differences between sites are significant at the $p=0.05$ level, or usually at a much lower level. It ought to be observed, however, that individuals with a strong or rather strong lustre (4-5 on the scale), even on the elytra, were found in both sites, though only some very few in the F-site, whereas strong to rather strong lustre was the rule in the H-site.

\subsection{Estimate of colour}

Colour of the elytra differed considerably between the two sites. Both males and females from the H-site (67-73\% of all individuals) were predominantly brownish to bright copper, especially males being bright in colour of the elytra (Table $3)$. In the F-site, the elytra of both sexes (70-76\% of all individuals) were predominantly black or black with a violet shade. As much as $30-40 \%$ of all individuals from the F-site had completely black elytra without any metal lustre, compared to only $0-2 \%$ of all individuals from the $\mathrm{H}$-site.

Colour of the pronotum differed between sites in about the same way as the elytra, but a more or less distinct purple shade or reflex was apparent in both sexes, especially when the colour was
Table 4. Per cent distribution of colour shades of pronotum in males and females of Carabus arvensis from the heath land ( $\mathrm{H}$-site) and the forest (F-site), estimated according to SIS (1990) and given colour nominations in English. Number of individuals, see Table 1.

Colour shade $\quad \frac{\text { Males }}{\text { H-site F-site }} \frac{\text { Females }}{\text { H-site F-site }}$

\begin{tabular}{|c|c|c|c|c|}
\hline \multicolumn{5}{|l|}{ Bright copper } \\
\hline to copper purple & 77 & 15 & 60 & 13 \\
\hline Dark copper to brownish & 0 & 0 & 3 & 0 \\
\hline \multicolumn{5}{|l|}{ Copper with greenish } \\
\hline shade & 3 & 0 & 3 & 0 \\
\hline Blackish brown & 0 & 0 & 5 & 0 \\
\hline Black with greenish shade & 8 & 0 & 2 & 2 \\
\hline Black with violet shade & 2 & 50 & 3 & 62 \\
\hline Black with purple shade & 10 & 19 & 17 & 19 \\
\hline Black, no metal lustre & 0 & 16 & 7 & 4 \\
\hline
\end{tabular}

bright copper (Table 4). The pronotum had usually slightly stronger colours than the elytra and there were little or no difference in colour between sexes. The basic colour of the pronotum was some kind of copper in as much as $70-80 \%$ of all individuals from the $\mathrm{H}$-site, whereas it was black in $85-87 \%$ of all individuals from the Fsite.

However, it should be noted that copper coloured individuals, though with a much lower frequency, did occur in the F-site, and black individuals in the H-site. The entire range, or almost so, of colours or brightness of the metal lustre in both elytra and pronotum was thus represented in both the heath and the forest site, though frequency differences in colours and degrees of metal lustre between habitats were striking.

\section{Discussion}

The landscape structure of the south-Swedish area studied has undergone considerable changes during the last one-two centuries. The F-site of the study was located in an area that was almost treeless in the early $19^{\text {th }}$ century, in those days being open land with an agriculture fighting against wind erosion and inland dune formation due to sand flight. $C$. arvensis is actually known from this area in the $19^{\text {th }}$ century according to a couple 
of preserved museum specimens. As, in those days, agricultural land with no forest prevailed, C. arvensis must have been an open land population, as is still the case with the heath population of this study, which differs so much from the present-day pine forest population of the former agricultural land. The populations of the two sites studied, situated ca $35 \mathrm{~km}$ apart, seem nowadays completely isolated from each other, as there are no known findings during the passed century from the area in between, where the Carabus fauna has been quite well studied. Isolation was probably not the case ca 200 years ago, though detailed information is lacking. It is well known that heath land in those days was much more widespread than today in the area surrounding the present-day heath site studied, whereas forest land was scanty also in this area.

Consequently, open-land conditions prevailed 150-200 years ago in both sites studied. It should be assumed that he $\mathrm{H}$-site population has been a heath population since long. The F-site population has more recently adapted to pine forest conditions, and the species is actually nowadays lacking or quite scarce in the open grassland of abandoned fields or pastures surrounding the forest. It seems unlikely that the individuals of the two present-day populations differed so much 100-200 years ago as they do today. A change towards darker colours and less brilliant lustre would have taken place in the pine-forest site, possibly as a recent adaptation to these changing conditions. However, it should be stressed that copper-coloured individuals with a bright lustre still occur, though with a quite low frequency, in the F-site population, and that some few dark-coloured individuals were actually found in the $\mathrm{H}$ site. It is the frequency, not the total range, of these contrasting appearances, that differs so greatly between the two habitats.

Explanations for the small but consistent mean differences in size variables measured are not evident but might be related to differences in nutritional status of the two populations. Explanations for the large mean differences in colour and lustre could be several. A genetic basis for polymorphism and heredity of elytral colour was proposed or demonstrated in carabids of other genera, as in Agonum decorum Say, 1823 (Liebherr 1983) and Poecilus lepidus (Leske, 1785)
(Paarmann et al. 2008), respectively. Although both $C$. arvensis populations studied were quite large, it cannot be completely excluded that differences (at least to some extent) could have been caused by genetic chance processes, such as genetic drift, e.g. initiated some year in the passed with very unfavourable weather conditions that reduced the population to a minimum.

That colour or lustre might play some role in the reproduction of $C$. arvensis seems less likely, as males and females did not differ much in these respects in the present study. However, surfaces with a high reflection index would loose more energy than other surfaces, thereby reducing the heating of the animal towards more optimum temperatures under hot open-land conditions in the summer. It is also possible that predators may avoid preying on animals with strong lustre and colours, and that such properties would be more favourable under open-land conditions.

\section{Conclusions}

C. arvensis individuals of the heath studied had significantly more brilliant metal lustre and in most cases lighter, vivid copper colour than individuals from the pine forest, which were typically black with a violet shade and slightly larger in size. The two populations are nowadays isolated from each other, which was probably not the case one or two centuries ago, when both sites studied were treeless open land. The usually blackish colour of the forest population could thus be a recent adaptation to changed environmental conditions, though some influence of genetic drift cannot be excluded.

\section{References}

Bailey, N. T. J. 1969: Statistical methods in biology. English Universities Press, London. 199 pp.

Deuve, Th. 2004: Illustrated catalogue of the genus Carabus of the world (Coleoptera: Carabidae). - Pensoft, Sofia-Moscow. 461 pp.

Frania, H. 1982: Altitudinal differentiation between adjacent populations of a ground beetle Elaphrus americanus Coleoptera Carabidae Elaphrini. - Canadian Journal of Zoology 60: 1930-1939.

Garbalinska, P. \& Sklodowski, J. 2008: Body size differen- 
tiation in selected carabid species inhabiting Puszcza Piska forest stands disturbed by the hurricane. - Baltic Journal of Coleopterology 8: 101-114.

Ikeda, H., Homma, K. \& Kubota, K. 2006: Body sizes of some carabid beetles on Sado Island, Japan, compared with the mainland. - Biogeography 8: 11-16.

Imura, Y. \& Muzisawa, K. 1996: The Carabus of the world. - Mushi-Sha's Iconographic Series of Insects, Vol. 2. Tokyo, Japan. 262 pp.

Lauterbach, A. W. 1964: Verbreitungs- und aktivitätsbestimmende Faktoren bei Carabiden in sauerländischen Wäldern. - Abhandlungen aus dem Landesmuseum für Naturkunde zu Münster in Westfalen 26: 1-100.

Liebherr, J. K. 1983: Genetic basis for polymorphism in the ground beetle Agonum decorum (Coleoptera, Carabidae). - Annals of the Entomological Society of America 76: 349-358.

Lindroth, C. H. 1985: The Carabidae Coleoptera of Fennoscandia and Denmark. - Fauna Entomologica Scandinavica 15: 1-232.

Magura, T. 2002: Carabids and forest edge: spatial pattern and edge effects. - Forest Ecology and Management 157: 23-37.

Okamoto, M., Kashiwai, N., Su, Z. H. \& Osawa, S. 2001: Sympatric convergence of the color pattern in the Chilean Ceroglossus ground beetles inferred from sequence comparisons of the mitochondrial ND5 gene. Journal of Molecular Evolution 53: 530-538.

Paarmann, W., Assmann, T., Mossakowski, D., Rohe, W. \& Lüchtrath, I. 2008: Heredity of the elytral colour in adults of Poecilus lepidus Leske (Coleoptera, Carabidae). - Proceedings of the $13^{\text {th }}$ European Carabidologists' Meeting, Blagoevgrad, August 20-24, 2007, p. 183-194.
Seago, A. E. 2009: Gold bugs and beyond: a review of iridescence and structural colour mechanisms in beetles (Coleoptera). - Journal of the Royal Society Interface 6, Suppl. 2: S165-S184.

SIS 1990: Swedish Standardisation Commission, Colour Atlas, $2^{\text {nd }}$ edition. Natural colour system and colour sample collections. - Scandinavian Colour Institute AB. Stockholm and Sarpsborg. (16), 44 pp.

Storre, I., Assman, T. \& Schmidt, G. H. 1996: Age structure of carabid beetles reproducing in spring: population-biological investigations by means of the corpus luteum. - Verhandlungen der Gesellschaft für Ökologie 26: 587-590.

Szyszko, J., Szujecki, A., Masur, S. \& Perlinski, S. 1978: Seasonal changes in the mean biomass of Carabus arcensis and Calathus erratus Coleoptera Carabidae individuals in fresh forest pine stands. - Ekologia polska 26: 297-304.

Turin, H., Penev, L. \& Casale, A. (eds.) 2003: The genus Carabus in Europe. A synthesis. -Fauna Europaea Evertebrata 2. - Pensoft, Sofia-Moscow. 511 pp.

Tyler, G. 2008a: Differences in abundance, species richness, and body size of ground beetles (Coleoptera: Carabidae) between beech (Fagus sylvatica L.) forests on Podzol and Cambisol. - Forest Ecology and Management 256: 2154-2159.

Tyler, G. 2008b: The ground beetle fauna (Coleoptera: Carabidae) of abandoned fields, as related to plant cover, previous management and succession stage. - Biodiversity and Conservation 17: 155-172.

Weller, B. \& Ganzhorn, J. 2004: Carabid beetle community composition, body size, and fluctuating asymmetry along an urban-rural gradient. — Basic and Applied Ecology 5: 193-201. 